How to Cite

Abolghasemi, S. J., Saeidi, P., \& Safarzad, R. (2018). Identifying and ranking the factors associated with supply chain management improvement using AHP method. International Journal of Business, Economics \& Management, 1(1), 38-52. https://doi.org/10.31295/ijbem.v1n1.26

\title{
Identifying and Ranking the Factors Associated with Supply Chain Management Improvement Using AHP Method
}

\author{
Seyed Jalal Abolghasemi \\ Islamic Azad University, Aliabad Katoul, Iran \\ Parviz Saeidi \\ Islamic Azad University, Aliabad Katoul, Iran \\ Reza Safarzad \\ Islamic Azad University, Aliabad Katoul, Iran
}

\begin{abstract}
Supply chain management includes integrated and coordinated guidance of all members of the supply chain to improve performance in order to increase efficiency and achieve greater profits; and supply chain managers look for ways of faster delivery of goods and services, costs reduction, and quality increase. The aim of this research is to identify and rank the factors associated with supply chain management improvement. Methods: The present study is an applied research in terms of its purpose and is a descriptive and survey study in terms of its methodology. The sample of this study was selected from the senior experts and the managers who are official members of Golestan Province Gas Company through the census method due to the limitation of decision making team. The data used in this study were obtained from two semi-structured questionnaires. First, to identify factors related to supply chain management improvement, the experts' views were listed and categorized into two parts of criteria and sub-criteria using structural analysis. Second, experts rated the criteria and sub criteria using AHP pair-wise comparison standard questionnaires and their ratings were considered in the calculation of points. To analyze the data, Expert Choice and Spss19 soft wares were used. Results: This study shows that, in the main criteria, marketing factors, weighing 0.318, were placed in the first rank followed by the financial, strategic and organizational relationships criteria. In ranking the sub-criteria, sub-criteria of study and identification of the supplier with a final weight of 0.084, product diversification strategies with a final weight of 0.068, and approaches the final cost of the product by the final weight of 0.066, ranked as the first, second and third respectively, were considered as the priorities related to supply chain management improvement from the experts' views.

Keywords---factors related to supply chain improvement, key processes of supply chain, supply chain management, supply chain.
\end{abstract}

\section{Introduction}

In this era, companies encounter fierce challenges and pressures of the competitive market such as globalization, competition and cooperation, diversity of customer requirements, and short life cycles of the products. Thus, the supply chain, as a matter of principle, has been of interest to corporate executives. In other words, senior managers, in addition to focusing on domestic activities, pay special attention to appropriate and timely communication and interaction with suppliers and customers and try to manage the supply chain of their products effectively and efficiently. To put it in other words, efforts to optimize organizational processes seem useless regardless of suppliers and customers; and organizations working together for common goals appears to have a better performance (Child hous \& Touil, 2003).

ISSN 2632-9476

Received Jan 10, 2018 / Accepted Jun 20, 2018 / Published Jul 05, 2018 
In recent years, the concept of Supply Chain Management is presented to depict the integrity of corporate operations from order to receipt of raw materials through production processes, and distribution and delivery of products to customers. This view enables the organizations to achieve quality improvement for products and customer service, at the expense of "reduced supply" (Ohdar \& Ray, 2004). One of the primary activities of a value chain model is that it provides customer some services, thereby adding value to the network value chain. Moreover, the goal of any organization is to maximize value creation, while minimizing costs. So, selecting a supplier plays a crucial role in the value chain; and the process of selecting the supplier is the most important variable in the effective management of the modern supply chain networks because access to high-quality products and customer satisfaction help the organizations (Bhattacharya et al., 2010).

Modern supply chains require IT support to satisfy different stakeholders. An IT application provides benefits to the supply-chain system in different ways and does not require any proof (Kumar et al., 2013).

The process of selecting good suppliers is very important in the purchase and efficient production. The distinction between the suppliers points out to the differences that originate from some features among them, such as organizational culture, manufacturing process, technology capabilities and distribution of geographic location (Chen \& Huang, 2010).

\section{Review of the Literature}

\section{a. Supply Chain}

The supply chain is a network of topological structure made up of autonomous or semi-autonomous corporations. These corporations, all together, perform procurement, production, delivery, and other things. There is a major corporation in each supply chain that is responsible for supply chain configuration based on data on demand as well as the use of financial flows, material, and information as a means to achieve the value throughout the chain (Lou et al., 2004).

The supply chain includes all activities related to the transformation of goods from raw material stage to the final state and also information flows associated with them (Kord \& Golshahi, 2012). In another definition: supply chain includes a network of facilities and distribution methods playing the role of procurement and preparation of materials, transportation of raw materials and final products and sending these products to customers. (Papageorgion, 2009).

\section{b. Supply Chain Management}

Morgan \& Hunt (1994) stressed the importance of establishing, developing and maintaining uniform and continuous relationships with customers, suppliers, distributors, enterprises, and groups with others specific goals (Polo et al., 2008).

Supply chain management is a way to strengthen the competitive forces that steadily becomes more significant (Vaaland \& Heide, 2007). The purpose of supply chain management is to improve the efficiency of delivery and product offering processes in the entire path of material supply chain to the final customer with minimal intermediation (Hoover et al., 2001).

The concept of supply chain management was created when the manufacturers experienced strategic partnership with their direct suppliers. SCM means a network of organizations involved in the processes and activities in an upside-down relationship, and creates value in the form of the form of products and services provided to the final customer (Christopher, 1998). In Papageorgion's (2009) view, supply chain consists of a network of facilities and distribution methods that play the role of material procurement and preparation, transportation of raw materials and final products, and bringing these products to the customers (Safarzad et al., 2014).

According to the Kumar et al., (2013), Most of the earlier studies were conducted without any product-specific supply chain in focus. However, it is important to understand differences in different supply chains. The supply chain of agri-food products in India is very much different from other conventional supply chains such as automotive products, electronics goods, personal computers or FMCGs. Some authors such as Charan et al., (2009); Gupta (2011); Humphrey (2003); Luthra et al., (2011); Sahay \& Mohan (2003); Viswanadham (2006) have recognized a supply chain of automotive products with names of one of key supply-chain partners like Maruti, Hero Honda, or in case of personal computers, with names such as of Dell or HP, and so on, but in a supply chain of agri-food products like pulses, food grain, etc., it is not possible to recognize it with a single name. Characteristics such as high degree of perishability, no proper identity of individual supply chain, limited outsourcing, unorganized structure and limited customer orientation make supply chain of agri-food products different from supply chains of other products (Aramyan et al., 2007; Joshi et al., 2009; Kumar \& Basu, 2008; Narula, 2009; Sagheer et al., 2009). 
Three main factors made the managers to pursue the subject of supply chain management seriously, including:

1. Information Revolution

2. Customer demand for purchasing high-quality products and services at a lower cost, through better delivery, more modern technology, and greater longevity which eventually led to increased competition among manufacturers.

3. The need for a new structure in inter-organization relations (Petri et al., 2007).

The place of supply chain management with regard to the type of the structure:

Table 1

The place of supply chain management (Kim, 2007)

\begin{tabular}{|c|c|c|c|}
\hline $\begin{array}{l}\text { Type of } \\
\text { organization }\end{array}$ & $\begin{array}{l}\text { The place of supply chain } \\
\text { management unit }\end{array}$ & $\begin{array}{l}\text { The domain under the control of } \\
\text { the management unit }\end{array}$ & Theoretical background \\
\hline $\begin{array}{l}\text { Non SCM-oriented } \\
\text { organization }\end{array}$ & $\begin{array}{l}\text { No special unit is responsible } \\
\text { for supply chain management, } \\
\text { though related activities are } \\
\text { done in the IS unit. }\end{array}$ & $\begin{array}{l}\text { Doing traditional activities that } \\
\text { control global units. Supply } \\
\text { chain activities are not performed } \\
\text { by a special unit. Planning and } \\
\text { deployment of SCMIS are done } \\
\text { by the IS unit. }\end{array}$ & $\begin{array}{l}\text { Lambert and Stock (1993) } \\
\text { Bowersox and Daugherty } \\
\text { (1995) Bowersox et al., } \\
\text { (2002) Monczka et al., } \\
\text { (2002) Head (2005) } \\
\text { Jabnoun and Sahraoui } \\
\text { (2004) }\end{array}$ \\
\hline $\begin{array}{l}\text { Functional } \\
\text { structure }\end{array}$ & $\begin{array}{l}\text { There is one exclusive unit for } \\
\text { SCM }\end{array}$ & $\begin{array}{l}\text { SCM unit carries out } \\
\text { traditional activities of SCM. } \\
\text { Both SCM and IS units are } \\
\text { responsible for planning and } \\
\text { implementing SCMIS. }\end{array}$ & $\begin{array}{l}\text { Lambert and Stock (1993) } \\
\text { Bowersox and Daugherty } \\
\text { (1995); Johannessen and } \\
\text { Solem (2002) }\end{array}$ \\
\hline $\begin{array}{l}\text { Integrated linear } \\
\text { structure }\end{array}$ & $\begin{array}{l}\text { Other function units are placed } \\
\text { at a lower position and this unit } \\
\text { controls all overall activities }\end{array}$ & $\begin{array}{l}\text { SCM unit integrates all } \\
\text { external task of the SCM that } \\
\text { includes is activities }\end{array}$ & $\begin{array}{l}\text { Monczja et al., (2002) } \\
\text { Johannessen and Solem } \\
\text { (2002) Jabnoun and } \\
\text { Sahraoui (2004) Head } \\
(2005)\end{array}$ \\
\hline
\end{tabular}

The Main Processes of the Supply Chain

\begin{tabular}{l|lll}
$\begin{array}{l}\text { The matrix } \\
\text { structure }\end{array}$ & $\begin{array}{l}\text { A unit with equal status with } \\
\text { the other units, but its } \\
\text { responsibility is coordination } \\
\text { and planning. }\end{array}$ & $\begin{array}{l}\text { SCM focuses on inter- } \\
\text { organization coordination } \\
\text { and its relationship with external } \\
\text { members }\end{array}$ & $\begin{array}{l}\text { Pritsker (1997) Johnson } \\
\text { (1997); Huang and Lin } \\
\text { (2002) Monczka } \text { et al., } \\
\text { (2002) Johannessen and } \\
\text { Solem (2002) Bowersox } \\
\text { et al., (2002) }\end{array}$ \\
$\begin{array}{l}\text { The staff structure } \\
\text { of the process }\end{array}$ & $\begin{array}{l}\text { SCM unit position is higher } \\
\text { than the other units, also } \\
\text { includes the IS unit, and is } \\
\text { responsible for the overall } \\
\text { coordination and } \\
\text { administrative tasks. }\end{array}$ & $\begin{array}{l}\text { SCM practical activities are } \\
\text { performed in the form of linear } \\
\text { task including IS unit. }\end{array}$ & $\begin{array}{l}\text { Benita } \text { et al., (1992) } \\
\text { Lambert and Stock (1993) } \\
\text { Bowersox and Daugherty } \\
\text { (1995) Johannessen and } \\
\text { Solem (2002) Monczka } \text { et } \\
\text { al., (2002) }\end{array}$ \\
\hline
\end{tabular}

Five main sections of the supply chain management are discussed in the following:

Planning- This is the strategic section of the supply chain management. It is the management of the resources that are used to meet customer requirements for your product or service you. Strategic planning is needed. Most of the planning process is devoted to implementation of measures to monitor the supply chain so that it would be optimized and cost-effective and meets the customer's desired quality and value.

Resources - choose suppliers and vendors who provide the products and services used in producing your required products and services. Determine procedures for pricing, delivery, and payment to the suppliers, provide a set of monitoring and optimization measures to communicate with them. Then, determine warehouse management 
processes including receiving emails, reviewing and transferring goods and services to their product lines, as well as how to pay to the suppliers.

Production - plan the activities needed for quality control production, packing, and preparing to send the emails. Measure quality levels, production output, and the employment of workers and employees.

Sending- this section is often called logistics; in this section, you should arrange the customers' received orders, prepare a network of warehouses, and choose ways of transporting the products to the customers and the payment methods.

Rejection- establish the section of network supply chain problems for rejection of defective goods from customers (Sezkeli, 2005).
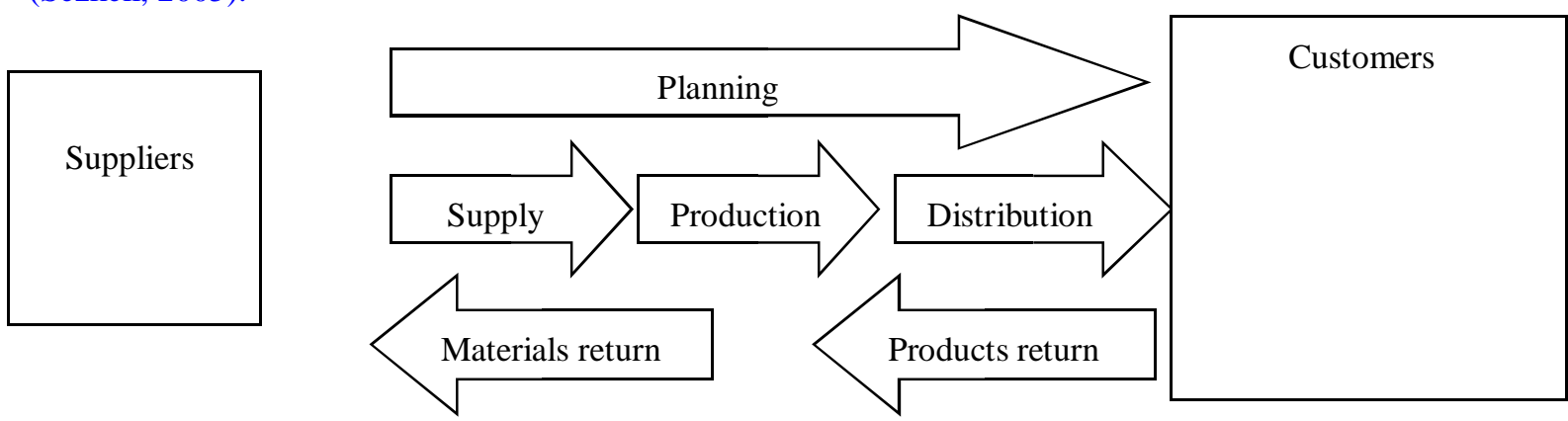

Fig. 1 The main supply chain processes that should be checked to asses(SSezkeli, 2005, p.5)

Background of the research

\begin{tabular}{|c|c|c|c|}
\hline Researcher & Subject & Year & Results \\
\hline $\begin{array}{l}\text { Xiaoyuan, } \\
\text { Jayashankar } \\
\text { and } \\
\text { Swaminathan }\end{array}$ & $\begin{array}{l}\text { Improvements in supply } \\
\text { chain management }\end{array}$ & 2015 & $\begin{array}{l}\text { Key issues related to supply chain management following the } \\
\text { discussion on the complexities associated with the supply chain } \\
\text { management are provided. After that, the inefficiencies of weak } \\
\text { supply chain management is discussed. Finally, a summary of } \\
\text { up-to-date research activities and discussion on the future } \\
\text { challenges related to supply chain management are provided. }\end{array}$ \\
\hline
\end{tabular}

$\begin{array}{cl}\begin{array}{c}\text { Abdul-Kader } \\ \text { and Shaik }\end{array} & \begin{array}{l}\text { The framework of } \\ \text { environmental criteria, } \\ \text { green criteria, and } \\ \text { organizational criteria } \\ \text { to select a green } \\ \text { supplier }\end{array} \\ \text { Safarzad et } & \begin{array}{l}\text { Identification and } \\ \text { evaluation of supply } \\ \text { chain agility through }\end{array} \\ & \text { AHP method. }\end{array}$

2014 It creates a hierarchy to assess criteria and sub-criteria of green suppliers which leads to the formulation of appropriate habitable strategies by managers.

2014 For the purposes of this study, three criteria and 12 sub-criteria of ranking of supply chain agility, based on the Lin et al. model were modified by the staffs and 81 options (components of supply chain agility), related to sub-criteria, were identified. After that, a questionnaire containing 41 factors, as the main factors, was distributed among 30 respondents. Among several options, the following expressions were selected as the most important factors from the participants' perspective: the electronic systems should be used in the interactions for the supply and delivery of goods. Software should be to detect future needs of the product candidates and ability to predict the market changes. 


\begin{tabular}{|c|c|c|c|}
\hline $\begin{array}{l}\text { Tseng, and } \\
\text { chiu }\end{array}$ & $\begin{array}{l}\text { Evaluation of the Green } \\
\text { supply chain } \\
\text { management of the } \\
\text { Company in linguistic } \\
\text { preferences }\end{array}$ & 2013 & $\begin{array}{l}\text { A total of } 18 \text { criteria- out of which the most important ones are } \\
\text { environmental standards, environmental management system, } \\
\text { the profitability of suppliers and close relationships with the } \\
\text { suppliers, were selected for the study and then fuzzy theory } \\
\text { was used to change linguistic criteria to definite numbers. }\end{array}$ \\
\hline Tseng & $\begin{array}{l}\text { Implementing green } \\
\text { supply chain } \\
\text { management for } \\
\text { selecting the } \\
\text { suppliers }\end{array}$ & 2012 & $\begin{array}{l}\text { Both environmental and non-environmental criteria were } \\
\text { developed in the under-investigation company and weight of } \\
\text { the criteria was determined based on two quantitative and } \\
\text { qualitative factors, and finally gray analysis method was used to } \\
\text { rank vendors. }\end{array}$ \\
\hline $\begin{array}{l}\text { Sila, } \\
\text { Ebrahimpour, } \\
\text { and Birkholz }\end{array}$ & $\begin{array}{l}\text { Quality in the supply } \\
\text { chain: an empirical } \\
\text { analysis. Supply Chain } \\
\text { Management }\end{array}$ & 2006 & $\begin{array}{l}\text { They showed that two activities of "supplier quality } \\
\text { management" and "focus on customer " are two important } \\
\text { activities of quality management that are included in the scope } \\
\text { of supply chain management specifically; thus, they offered that } \\
\text { managers should develop activities based on cooperation and } \\
\text { interaction at the supply chain level and integrate upstream and } \\
\text { downstream processes of quality improvement in order to }\end{array}$ \\
\hline
\end{tabular}

The Proposed Model for the Research
2013 A total of 18 criteria- out of which the most important ones are environmental standards, environmental management system, the profitability of suppliers and close relationships with the suppliers, were selected for the study and then fuzzy theory developed in the under-investigation company and weight of the criteria was determined based on two quantitative and qualitative factors, and finally gray analysis method was used to They showed that two activities of "supplier quality management" and "focus on customer " are two important activities of quality management that are included in the scope managers should develop activities based on cooperation and downstream processes of quality improvement in order to

The aim of this study is to identify and rank the factors related to supply chain management improvement in Golestan province gas companies using AHP hierarchal analysis method. The research model is provided in the following pattern based on theoretical research background as well as expert opinion.

Each of the criteria and sub-criteria of the model has been extracted from various articles. Organizational factors are extracted from Shafiee (2013), Kelidbory et al., (2013), Ahmad et al., (2012), and Xiaoyuan et al., (2015). Marketing factors are introduced by Golshahi (2012) and Sila et al., (2006). Financial factors are discussed by Javadian (2014), Kord \& Golshahi (2012), Dezh et al., (2013), and Safaee et al., (2012). Strategic relationships are explained by Ghassemieh et al., (2012) and Abdul-Kader \& Shaik (2014).

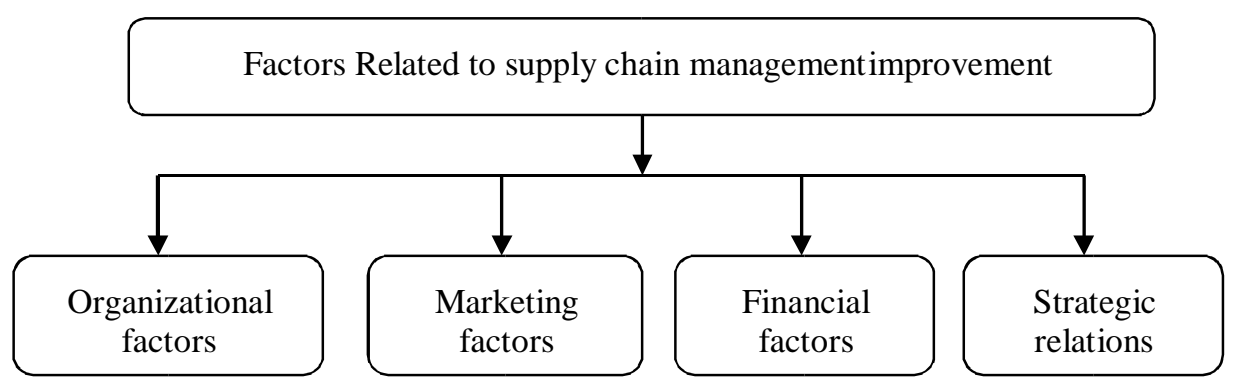

Fig 2 The conceptual model of the research

\section{Research Methods}

This study is an applied research in terms of its objectives and is a descriptive and survey one in terms of its method. The sample of this study was selected from the senior experts and the managers who are official members of members of Golestan Province Gas Company through the census method due to the limitation of decision-making team.

\section{Research Instruments}

In this study, descriptive statistics such as frequency distribution table, percentages, and charts are used. After collecting research corpus and the expert opinions, AHP hierarchical fuzzy analysis questionnaire was developed to 
analyze the data. After gathering the responded questionnaires, they were analyzed by soft-wares such as Excel and Expert Choice. Multi-criteria decision-making methods used in this study has several advantages such as taking into account the uncertainty related to the subjective preferences of decision makers.

\section{The Validity and Reliability of the Instrument}

The validity of the instruments used in this study is, in a sense, a kind of logical or content validity that is related to the employed method. In paired comparison method, all the factors are assessed together that it illuminates any probability related to ignoring one factor or one question.

Reliability of the scale and ranking the factors associated with supply chain management improvement were done through pre-test which is presented in Table 2. Cronbach's alpha values obtained for sub-indices are generally acceptable, so the reliability of the questionnaire is confirmed.

Table 2

Reliability of the questionnaire

\begin{tabular}{cc}
\hline \multicolumn{2}{c}{ Reliability statics } \\
\hline Cronbach,s Alpha & Number. of Items \\
\hline 0.87 & 20 \\
\hline
\end{tabular}

\section{Results and Analysis}

\section{Data Analysis}

According to analysis, factors related supply chain management improve were identified in the 4 criteria and 20 subcriteria, and the hierarchical structure of the questionnaire is as follow. 


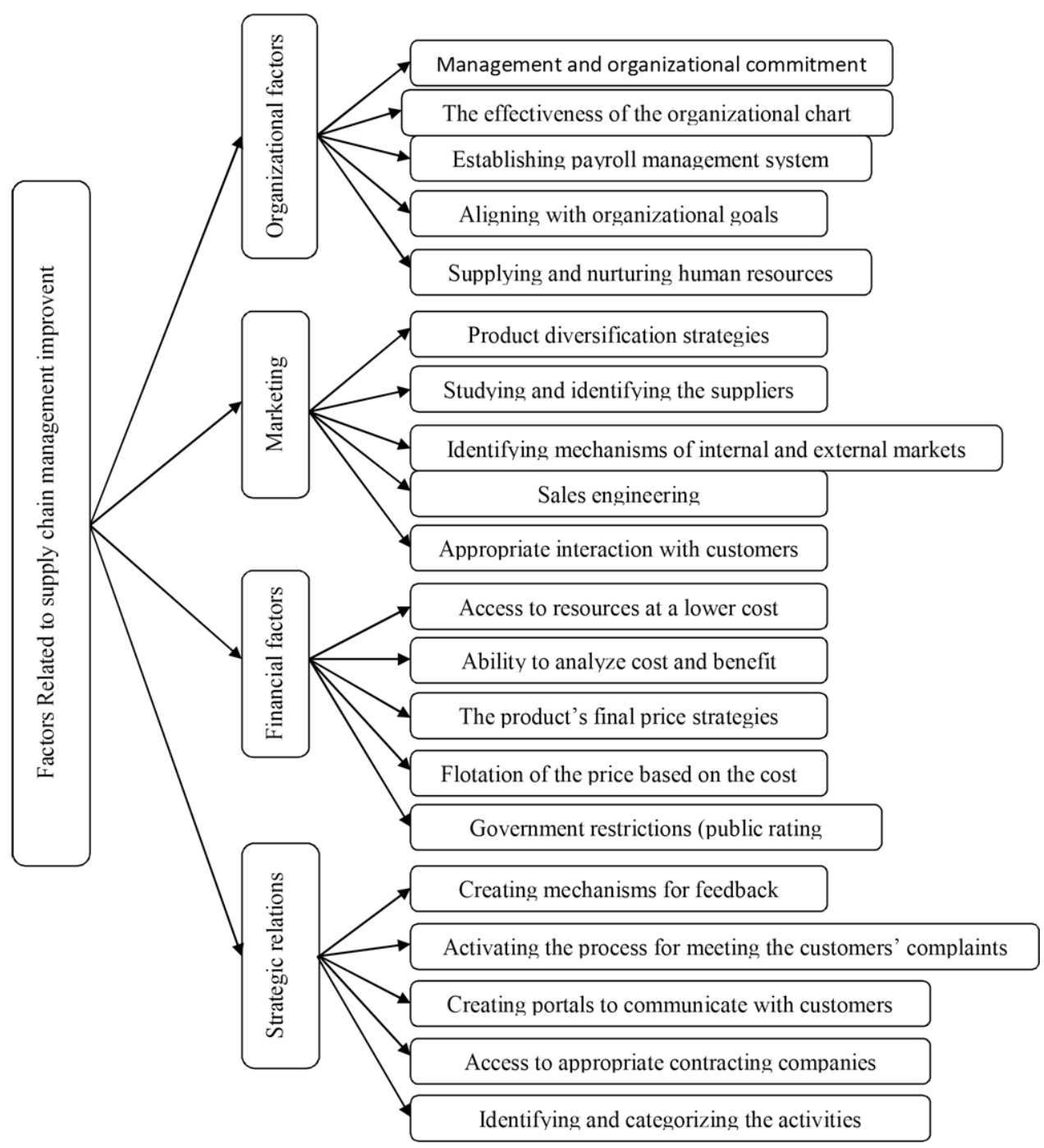

Figure 3. The hierarchical structure of the factors related to supply chain management improvement

\section{Calculating Weights of Various Levels}

In this step, to calculate the relative importance (weight) of each of the different levels (Level I, Level II, and Level III), a questionnaire in accordance with the AHP format (Pairwise comparison test) was provided and distributed to collect the opinions and comments of the decision-making team. The questionnaire includes a matrix for pairwise comparison of the factors. So, their numbers are equal to the number of the comparisons.

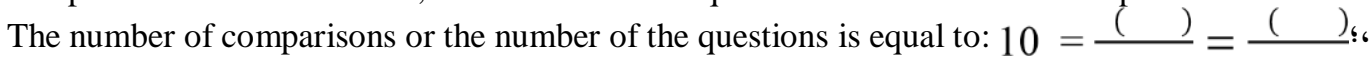

In other words, there are 10 pairwise comparisons for sub-criteria of each factor. After collecting the questionnaires, the rate of adjustment of each factor was examined individually from the 30 collected questionnaires. That questionnaire which their adjustment rate was less than or equal to 0.1 were analyzed and the respondent's opinions were combined using Expert Choice 11 software. 
Calculating Weight of the Main Factors (level II)

Table 3

The integrated matrix of pairwise comparisons of the main factors associated with supply chain management improvement

\begin{tabular}{l|llllll}
\hline Main factors & $\begin{array}{l}\text { Organizational } \\
\text { factors }\end{array}$ & $\begin{array}{l}\text { Marketing } \\
\text { factors }\end{array}$ & $\begin{array}{l}\text { Financial } \\
\text { factors }\end{array}$ & $\begin{array}{l}\text { Strategic } \\
\text { relations }\end{array}$ & Weights & rank \\
\hline Organizational factors & 1 & 0.71 & 0.66 & 1.21 & 0.215 & 4 \\
Marketing factors & 1.41 & 1 & 1.34 & 1.41 & 0.318 & 1 \\
Financial factors & 1.50 & 0.75 & 1 & 0.94 & .247 & 2 \\
Strategic relations & 0.83 & 0.71 & $1.06 \quad$ IR=0.01 $<0.1$ & 0.220 & 3 \\
& & \multicolumn{7}{c}{} \\
\hline
\end{tabular}

The matrix inconsistency index is 0.01 , and this value is less than 0.1 ; therefore, the validity of the matrix is acceptable. Among the four factors- associated with supply chain management improvement- that were compared, according to the above matrix, criteria of marketing factors weighing 0.318 was ranked in the first place of importance followed by financial factors weighing 0.247 ranked in second place of importance, criteria of strategic relations with a weight of 0.220 ranked in the third place, and organizational factors criteria with a weight of 0.215 ranked in the fourth place of importance.

Calculating Weight of the Sub-factors (level III)

Table 4

The integrated matrix of pairwise comparisons of organizational sub-factors

\begin{tabular}{|c|c|c|c|c|c|c|c|}
\hline Sub-factors & $\begin{array}{l}\text { Management } \\
\text { and } \\
\text { organizational } \\
\text { commitment }\end{array}$ & $\begin{array}{l}\text { The } \\
\text { effectiveness } \\
\text { of the } \\
\text { organizational } \\
\text { chart }\end{array}$ & \multicolumn{2}{|c|}{$\begin{array}{l}\text { Establishing Aligning with } \\
\text { payroll organizational } \\
\text { management goals } \\
\text { system }\end{array}$} & $\begin{array}{l}\text { Supplying } \\
\text { and } \\
\text { nurturing } \\
\text { human } \\
\text { resources }\end{array}$ & Weight & rank \\
\hline $\begin{array}{l}\text { Management and } \\
\text { organizational } \\
\text { commitment }\end{array}$ & 1 & 0.73 & 0.65 & 1.29 & 1.41 & 0.194 & 2 \\
\hline $\begin{array}{l}\text { The effectiveness } \\
\text { of the } \\
\text { organizational } \\
\text { chart }\end{array}$ & 1.36 & 1 & 1.48 & 1.63 & 0.79 & 0.240 & 1 \\
\hline $\begin{array}{l}\text { Establishing } \\
\text { payroll } \\
\text { management } \\
\text { system }\end{array}$ & 1.54 & 0.67 & 1 & 0.87 & 0.85 & 0.189 & 3 \\
\hline $\begin{array}{l}\text { Aligning with } \\
\text { organizational } \\
\text { goals }\end{array}$ & 0.77 & 0.61 & 1.15 & 1 & 1.26 & 0.183 & 4 \\
\hline $\begin{array}{l}\text { Supplying and } \\
\text { nurturing human } \\
\text { resources }\end{array}$ & 0.71 & 1.26 & 1.18 & $\begin{array}{l}0.79 \\
\mathrm{IR}=0.02<0.1\end{array}$ & 1 & 0.194 & 2 \\
\hline
\end{tabular}

The matrix inconsistency index is 0.02 , and this value is less than 0.1 , so the validity of this matrix is acceptable. Among the five sub-criteria of organizational factors which were compared, according to the above matrix, sub- 
criteria of the effectiveness of the organizational chart weighing 0.240 was ranked in the first place of importance, followed by sub-criteria of management and organizational commitment and Supplying and nurturing human resources with a weight of 0.194 ranked in the second place of importance, establishing payroll management system with a weight of 0.189 ranked in the third place of importance, and sub-criteria of aligning with organizational goals with a weight of 0.183 placed in fourth rank of importance.

Table 5

The integrated matrix of pairwise comparisons of marketing sub-factors

\begin{tabular}{|c|c|c|c|c|c|c|c|}
\hline Sub-factors & $\begin{array}{l}\text { Product } \\
\text { diversification } \\
\text { strategies }\end{array}$ & $\begin{array}{l}\text { Studying } \\
\text { and } \\
\text { identifying } \\
\text { the } \\
\text { suppliers }\end{array}$ & $\begin{array}{l}\text { Identifying } \\
\text { mechanisms } \\
\text { of internal } \\
\text { and external } \\
\text { markets }\end{array}$ & $\begin{array}{l}\text { Sales } \\
\text { engineering }\end{array}$ & $\begin{array}{l}\text { Appropriate } \\
\text { interaction } \\
\text { with } \\
\text { customers }\end{array}$ & Weight & Rank \\
\hline $\begin{array}{l}\text { Product } \\
\text { diversification } \\
\text { strategies }\end{array}$ & 1 & 0.56 & 2.74 & 1.65 & 1.92 & 0.258 & 2 \\
\hline $\begin{array}{l}\text { Studying and } \\
\text { identifying the } \\
\text { suppliers }\end{array}$ & 1.78 & 1 & 1.54 & 2.08 & 2.23 & 0.313 & 1 \\
\hline $\begin{array}{l}\text { Identifying } \\
\text { mechanisms of } \\
\text { internal and } \\
\text { external } \\
\text { markets }\end{array}$ & 0.36 & 0.65 & 1 & 0.62 & 0.55 & 0.116 & 5 \\
\hline $\begin{array}{l}\text { Sales } \\
\text { engineering }\end{array}$ & 0.61 & 0.48 & 1.61 & 1 & 1.92 & 0.181 & 3 \\
\hline $\begin{array}{l}\text { Appropriate } \\
\text { interaction with } \\
\text { customers }\end{array}$ & 0.52 & 0.45 & $\begin{array}{l}1.83 \\
\quad \mathrm{IR}=0\end{array}$ & $\begin{array}{c}0.52 \\
02<0.1\end{array}$ & 1 & 0.138 & 4 \\
\hline
\end{tabular}

The matrix inconsistency index is 0.02 , and this value is less than 0 , thus the validity of this matrix is acceptable. Among the five sub-criteria of the marketing factors that were compared, according to the above matrix, sub-criteria of Studying and identifying the suppliers weighing 0.313 was ranked in the first place of importance, then subcriteria of product diversification strategies with a weight of 0.252 was ranked in the second place of importance, followed by the sub-criteria of sales Engineering with a weight of 0.181 in the third place, sub-criteria of appropriate interaction with customers weighing 0.138 in fourth place of importance, and sub-criteria of Identifying mechanisms of internal and external markets with a weight of 0.116 placed in the fifth rank of importance. 


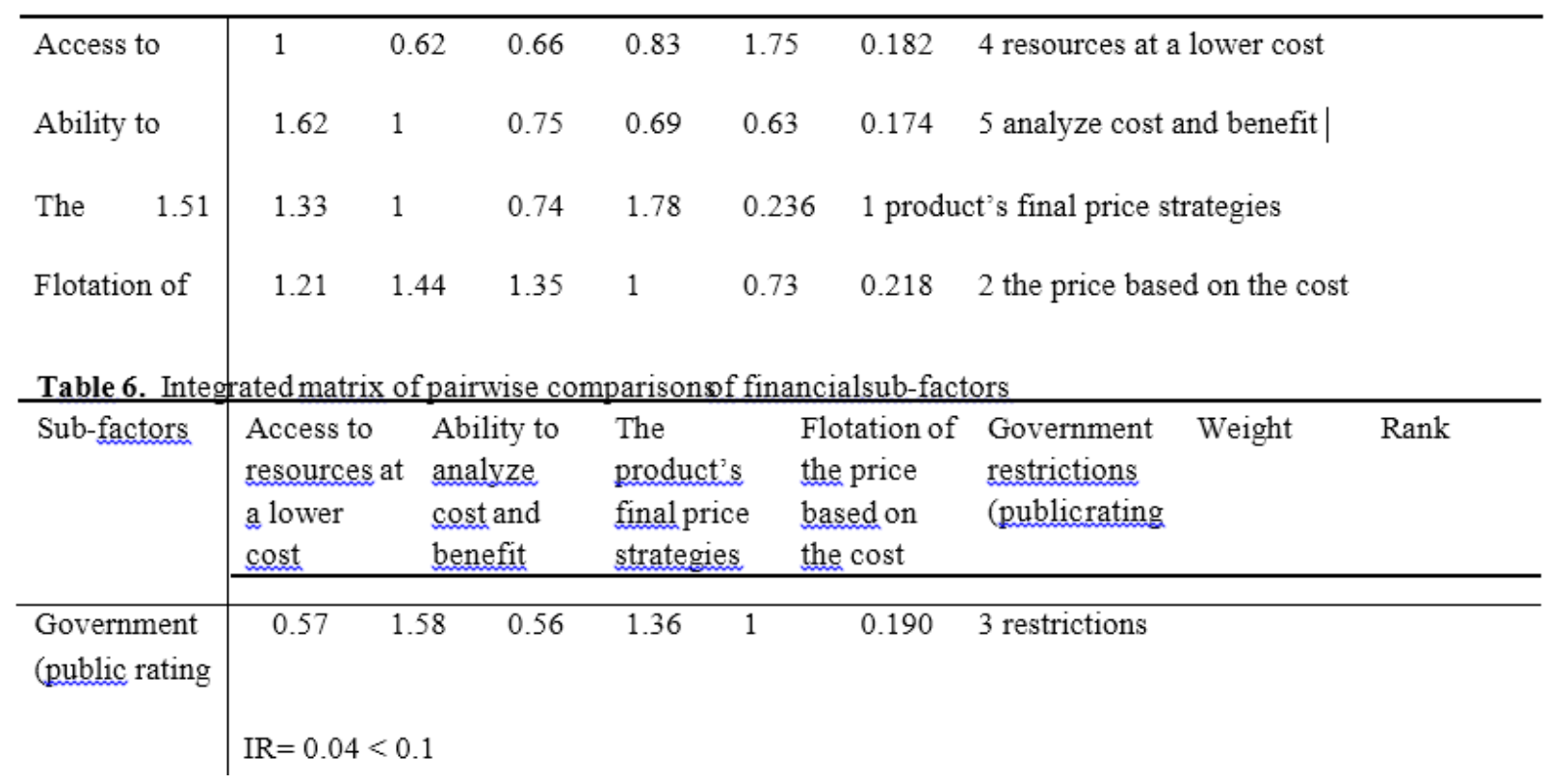

The matrix inconsistency index is 0.04 , and this value is less than 0.1 , so the validity of this matrix is acceptable. Among the five sub-criteria of financial factors were which compared, the product's final price strategies with a weight of 0.236 was ranked in the first place of importance, Flotation of the price based on the cost with a weight of 0.218 was ranked in the second place of importance, government restrictions with a weight of 0.190 was ranked in third place, subcriteria of access to resources at a lower cost with a weight of 0.182 was ranked in the fourth place of importance, and sub-criteria of Ability to analyze cost and benefit with a weight of

0.174 was ranked in the fifth place of importance.

Table 7

The integrated matrix of pairwise comparison of strategic relations sub-factors

\begin{tabular}{|c|c|c|c|c|c|c|c|c|c|c|}
\hline \multirow{2}{*}{$\begin{array}{l}\text { Sub-factors } \\
\text { Creating } \\
\text { mechanisms } \\
\text { for feedback }\end{array}$} & \multicolumn{2}{|c|}{$\begin{array}{l}\text { Creating } \\
\text { mechanism } \\
\text { s for } \\
\text { feedback }\end{array}$} & $\begin{array}{l}\text { Activating } \\
\text { the process } \\
\text { for meeting } \\
\text { the } \\
\text { customers' } \\
\text { complaints }\end{array}$ & \multicolumn{2}{|c|}{$\begin{array}{l}\text { Creating } \\
\text { portals to } \\
\text { communicate } \\
\text { with } \\
\text { customers }\end{array}$} & \multicolumn{2}{|c|}{$\begin{array}{l}\text { Access to } \\
\text { appropriate } \\
\text { contracting } \\
\text { companies }\end{array}$} & \multirow[t]{2}{*}{$\begin{array}{l}\text { Identifying } \\
\text { and } \\
\text { categorizing } \\
\text { the activities } \\
0.67\end{array}$} & \multirow{2}{*}{$\begin{array}{l}\text { Weight } \\
0.220\end{array}$} & \multirow{2}{*}{$\begin{array}{l}\text { Rank } \\
\\
2\end{array}$} \\
\hline & \multicolumn{2}{|l|}{1} & 1.32 & \multicolumn{2}{|c|}{1.36} & \multicolumn{2}{|l|}{1.51} & & & \\
\hline $\begin{array}{l}\text { Activating the } \\
\text { complaints }\end{array}$ & 0.76 & 1 & 1.29 & 1.65 & 0.64 & 0.198 & \multicolumn{4}{|c|}{3 process for meeting the customers' } \\
\hline Creating portals & 0.73 & 0.77 & 1 & 1.72 & 1 & 0.196 & \multirow{3}{*}{\multicolumn{4}{|c|}{$\begin{array}{l}4 \text { to communicate with customers } \\
5 \text { appropriate contracting companies } \\
1 \text { categorizing the activities }\end{array}$}} \\
\hline Access to & 0.66 & 0.61 & 0.58 & 1 & 1.01 & 0.150 & & & & \\
\hline \multirow[t]{2}{*}{ Identifying and } & 1.49 & 1.55 & 1 & 0.99 & 1 & 0.237 & & & & \\
\hline & \multicolumn{5}{|c|}{$\mathrm{IR}=0.03<0.1$} & & & & & \\
\hline
\end{tabular}

The matrix inconsistency index is 0.03 , and this value is less than 0.1 , so the validity of this matrix is acceptable. Among the five sub-criteria of the strategic relations which were compared with respect to the above sub-criteria matrix, to identifying and categorizing activities with a weight of 0.237 was ranked in the first place, sub-criteria of 
creating mechanisms for feedback with a weight of 0.220 was ranked in the second place of importance, Activating the process for meeting the customers' complaints with a weight of 0.198 was ranked in the third place, Creating portals to communicate with customers with a weight of 0.196 was placed in the fourth place, and Access to appropriate contracting companies with a weight of 0.150 was ranked in the fifth place of importance.

\section{Step Three: The Final Weight of the factors and Ranking}

The matrix inconsistency index is 0.01 , and this value is less than 0.1 , so the validity of this matrix is acceptable.

\section{Final Weights of Sub-criteria of the Factors Related to Supply Chain Management Improvement}

Out of the 20 sub-criteria categorized under four main factors related to supply chain management improvement that was examined, a comprehensive ranking of 20 sub-criteria is presented in Table 8 to determine which sub-criteria gained the higher priority and which gained the lower priority; and ratings of 1 to 20 belong to which sub-criteria in general.

Table 8

Ranking Factors Related to supply chain management improvement based on Analytic Hierarchy Process (AHP)

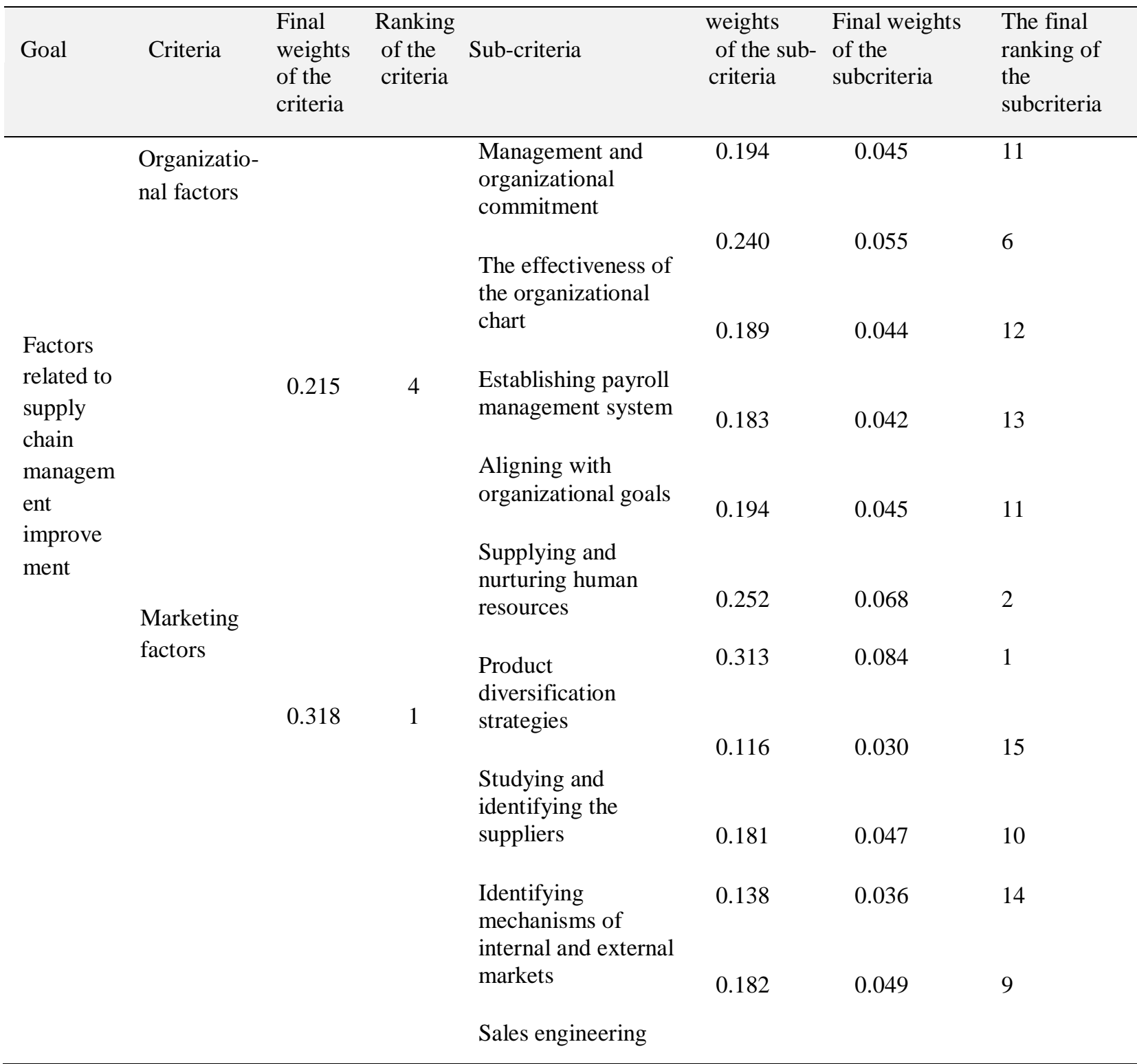




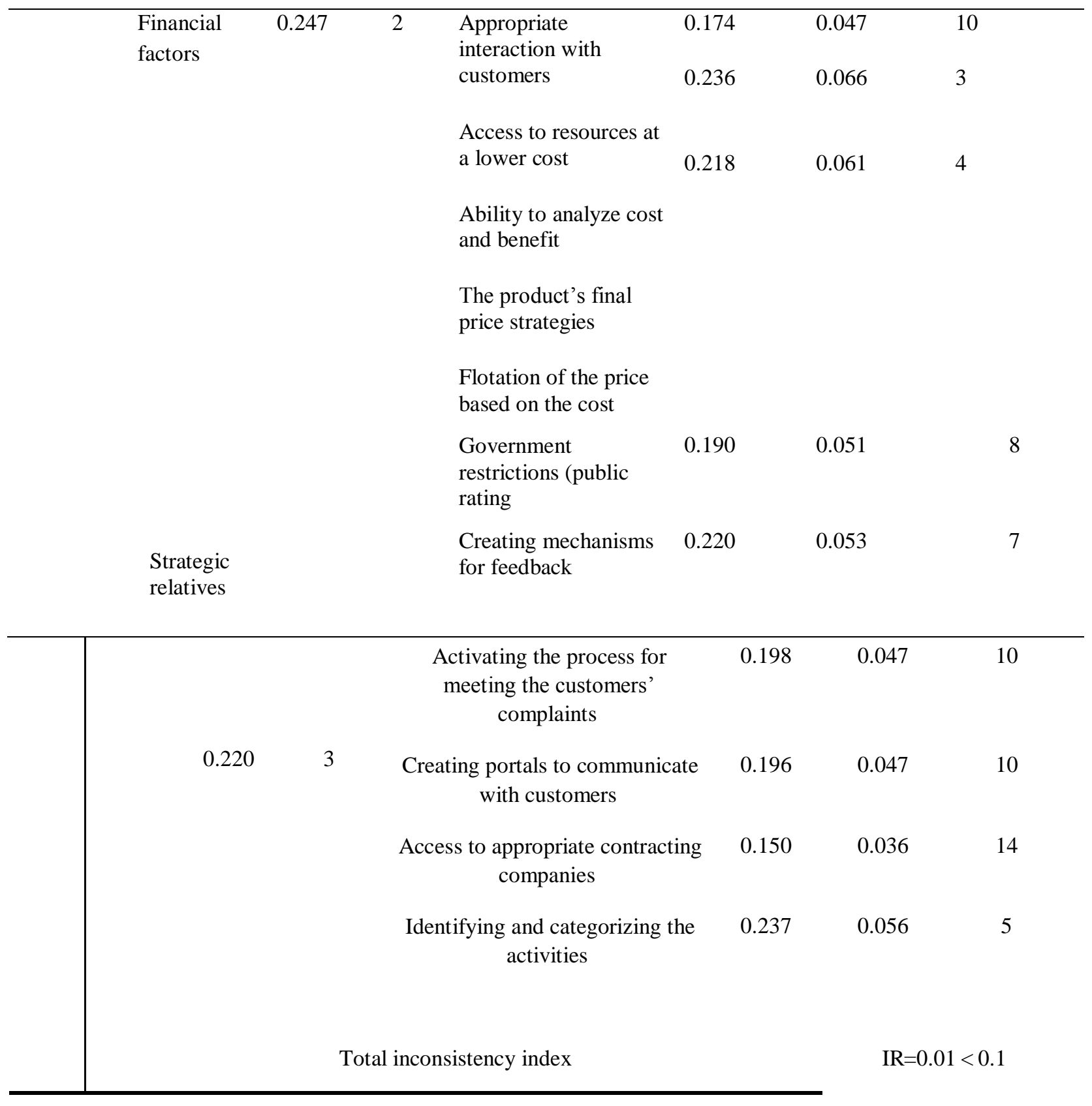

According to Table 8 sub-criteria of Studying and identifying the suppliers with a final weight of 0.084 ranked in the first place, sub-criteria of product diversification strategies with a final weight of 0.068 ranked in the second place, sub-criteria of the product's final price strategies with a final weight of 0.066 ranked in the third place of importance, sub-criteria of flotation price based on the cost with the final weight of 0.061 ranked in the fourth place, and access to appropriate contracting companies, appropriate interaction with customers and identifying mechanisms of internal and external market with final weights of $0.036,0.036$, and 0.030 were ranked in the 14 th and 15 th place of importance.

\section{Conclusion}

The present study aimed to assess factors associated with supply chain management improvement in Golestan Province Gas Company. After identifying the associated factors, they were ranked with the use of AHP hierarchical method; and the results showed that marketing factors, financial factors, strategic relations, and organizational 
factors obtained the highest priorities, respectively. The results of Kelidbory et al., (1393), show that use of a higher level of supply chain management practices and competitive advantage have a positive impact on organizational performance improvement; as well the use of supply chain management practices have a positive impact on the competitive advantages. In the era of knowledge, those organizations are successful that employ the strategies based on competitive advantages quickly and refine and improve processes and operations wherever necessary by learning from the market and customers. One of the primary activities of a value chain model is to provide customer services by which add a value to the value chain network. Moreover, the goal of any organization is to maximize value while the costs are kept at a minimum. So selecting a supplier plays a crucial role in the value chain and the process of supplier election is the most important variable in the effective management of modern supply chain networks because access to high quality products and customer satisfaction helps the organizations. Business always relates to the supply chain. That means the companies buy raw materials, components, and accessories used to create their products and services, and deliver them to customers who purchase their products. What is new is that the speed by which goods and services pass the chains related to the supply has significantly increased because advances in computer and communication have increased exchange rate of information. Though, a company just sees its direct providers and buyers. The group of buyers and customers are quite complex (Hosseini \& Sheikhi, 2012). Xiaoyuan et al., (2015), stated that supply chain management is an important aspect of any business. Javadian (2015), declared that when the main factors influencing the behavior of the whole system and the relationships between them are well-known, three policy measures are implemented and suggested in the model to improve the known indices of supply chain performance evaluation. The policies include reducing the number of lost sales, reducing the inventory and getting the right information which implementation has improved indices. The results enable us to predict the

results of any change in the variables, relationships, or chain structure that is very important due to the complexity of the supply chain.

\section{Acknowledgements}

The author would like to thank the editor for their valuable time and advice. 


\section{References}

Adetunji, A. T., Adetunji, A. V., Adeleke, E. O., \& Madubuike, S. C. (2017). Deregulation: The Effect of Market-led Approach to Nigerian Universities Management. International Journal of Social Sciences and Humanities (IJSSH), l(1), 1-8.

Ahmadi, S. A. A., Afshari, M. A., \& Shekari, H. (2013). A model for evaluating the success of organizations in green supply chain management with electing green supplier approach in Iran Alloy Steel Company. Quarterly Journal of Commerce (special issue), 95-127.

Aramyan, L. H., Oude Lansink, A. G., Van Der Vorst, J. G., \& Van Kooten, O. (2007). Performance measurement in agri-food supply chains: a case study. Supply Chain Management: An International Journal, 12(4), 304-315.

Bhattacharya, A., Geraghty, J., \& Young, P. (2010). Supplier selection paradigm: An integrated hierarchical QFD methodology under multiple-criteria environment. Applied Soft Computing, 10(4), 1013-1027.

Chen, C. T., Lin, C. T., \& Huang, S. F. (2006). A fuzzy approach for supplier evaluation and selection in supply chain management. International journal of production economics, 102(2), 289-301.

Dezh, G., Ayranban, S. J., Seyedi, S. M. (2014). Ranking vendors based on selected indicators in the dairy industry in green supply chain: A Case Study in Sobhe Sepid Company, Journal of Research in Operations and Applications, 1 (40), 22-35.

Ghassemieh, R., Yousefi, SH, \& Dastranj, A. (2013). Identifying and ranking the factors affecting supply chain management improvement using Multi-Attribute Decision Making Techniques (Case Study). Proceedings of the National Conference of Industrial and Systems Engineering.

Hoover Jr, W. E., Eloranta, E., Holmström, J., \& Huttunen, K. (2002). Managing the demand-supply chain: Value innovations for customer satisfaction. John Wiley \& sons.

Hosseini, S. M., \& Sheikhi, N. (2012). Clarifying the strategic role of supply chain management operations in the company's performance improvement: studying Iran's food industry. Strategic Management Studies, 10, 3560.

Javadian, N., Khani, M., Mahdavi, I. (2012). Identification of factors affecting supply chain performance and its improvement using system dynamics: Daroogar Company. Management Studies in Iran, 3, 39-58.

Joshi, R., Banwet, D. K., \& Shankar, R. (2009). Indian cold chain: modeling the inhibitors. British Food Journal, 111(11), 1260-1283.

Kelidbory, M., \& Azimi, L., (2014). Assessing supply chain management quality and its impact on the performance of casting car pieces company in Iran. Iranian Journal of Science and Management, 7(25), 89-112.

Kim, S. W. (2007). Organizational structures and the performance of supply chain management. International Journal of Production Economics, 106(2), 323-345.

Kord, B., \& Golshahi, H.R. (2013). Identifying and prioritizing the factors of success in the implementation of supply chain management using fuzzy decision-making techniques. Scientific journal of Technology of Cement, 63, 3744.

Kumar, M., \& Basu, P. (2008). Perspectives of productivity growth in Indian food industry: a data envelopment analysis. International Journal of Productivity and Performance Management, 57(7), 503-522.

Kumar, R., Agrawal, R., \& Sharma, V. (2013). e-Applications in Indian agri-food supply chain: Relationship among enablers. Global business review, 14(4), 711-727.

Lou, P., Chen, Y. P., \& Ai, W. (2004). Study on multi-agent-based agile supply chain management. The international journal of advanced manufacturing technology, 23(3-4), 197-203.

Martini, I. A. O., Lasmi, N. W., Jaya, N. K., \& Sutrisni, N. K. E. (2017). Improving Cooperative Performance through Human Resource Development Efforts. International Journal of Social Sciences and Humanities (IJSSH), 1(3), 49-58.

Ohdar, R., \& Ray, P. K. (2004). Performance measurement and evaluation of suppliers in supply chain: an evolutionary fuzzy-based approach. Journal of Manufacturing Technology Management, 15(8), 723-734.

Papageorgiou, L. G. (2009). Supply chain optimisation for the process industries: Advances and opportunities. Computers \& Chemical Engineering, 33(12), 1931-1938.

Petersen, K. J., Handfield, R. B., \& Ragatz, G. L. (2005). Supplier integration into new product development: coordinating product, process and supply chain design. Journal of operations management, 23(3-4), 371-388.

Petersen, K. J., Handfield, R. B., \& Ragatz, G. L. (2005). Supplier integration into new product development: coordinating product, process and supply chain design. Journal of operations management, 23(3-4), 371-388.

Quayle, M. (2003). A study of supply chain management practice in UK industrial SMEs. Supply Chain Management: An International Journal, 8(1), 79-86. 
Safaee, A. H., Tabibi, M. R. \& Hajiabadi, F. (2013). Presenting a hybrid ANP-DEMATEL fuzzy approach to prioritize evaluation criteria of green supplier performance: Iran Heavy Diesel Company. Management Research in Iran, 17(3), 129-149.

Safarzad.R., Ebrahimy. A.H., Mehrani. H., (2014), Identifying and Evaluating Agility Indicators of Supply Chain AHP method.(A Case Study: Golestan Gas Company), Journal of Applied Sciences Research, 2014 Special; 10(6): pages 472-477.

Sagheer, S., Yadav, S.S., \& Deshmukh, S.G. (2009). Developing a conceptual framework for assessing competitiveness of India's agrifood chain. International Journal of Emerging Markets, 4(2), 137-159.

Sezkeli, H. (2005). Supply chain management and advanced planning-basics, overview and challenges. European journal of operational research, 163, 575-588.

Shafiee, A., \& Nazeri, M., (2014). Supply Chain Management. Master's thesis, Executive Management, Azad University of Tehran.

Shaik, M., \& Abdul-Kader, W. (2011). Green supplier selection generic framework: a multi-attribute utility theory approach. International Journal of Sustainable Engineering, 4(01), 37-56.

Sila I, Ebrahimpour M, Birkholz C (2006). Quality in supply chains: an empirical analysis. Supply Chain Management: An Internattional Journal; 11(6): 491-502.

Suryani, S. A. M. P., \& Arya, I. W. (2017). Improving the Quality of Tilapia (Oreochromis niloticus) With consumption measures Leaf Extract Neem (Azadirachta indica A. Juss) as Antiparasitic. International Journal of Life Sciences (IJLS), 1(3), 28-37.

Swaminathan, J. M. Lauren Xiaoyuan Lu Jayashankar M. Swaminathan Kenan-Flagler Business School, University of North Carolina at Chapel Hill, Chapel Hill, North Carolina, USA Email: lauren_lu@ unc. edu, jay_swaminathan@unc.edu.

Tseng, m,. (2012). from reversed logistics to green supply chains, "Supply Chain Management", Vol. 4 No. 3, pp. 129-34.

Tseng, m. 1. and chiu, s. f.. (2013). "Evaluating firm's green supply chain management in linguistic preferences", "Journal of Cleaner Production", 22 (3), 265-289.

Vaaland, T. and Heide, M., (2007), "Can the SME survice the supply chain challenges", Supply Chain Management: An International Journal, Vol. 12 No. 6, pp. 20-31. 